IRA-International Journal of Applied Sciences

ISSN 2455-4499; Vol.13, Issue 01 (October 2018)

Pg. no. 1-13.

Institute of Research Advances

https://research-advances.org/index.php/IRAJAS

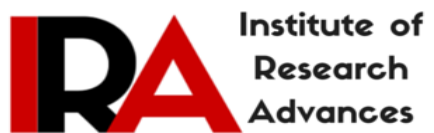

\title{
Land Cover/Land Use Trends along the Blue Nile River Blue Nile State - Sudan
}

\author{
Osman E.H. ${ }^{1}$, Gumaa Y.S.A. ${ }^{2}$ and Elhag A.M.H. ${ }^{3 \#}$ \\ ${ }^{1}$ University of Bahri, College of Natural Resources, Forest Department, Ministry of Higher Education \\ and Scientific Research, Khartoum North ( Al- Kadaro) Sudan. \\ ${ }^{2}$ Ministry of Agriculture \& Forestry, General Forestry Administration, Blue Nile State, Sudan \\ ${ }^{3}$ University of Bahri, College of Natural Resources, Basic Science Department, Ministry of Higher \\ Education and Scientific Research, Khartoum North ( Al- Kadaro) Sudan.
}

\#corresponding author.

Type of Review: Peer Reviewed.

DOl: http://dx.doi.org/10.21013/jas.v13.n1.p1

\section{How to cite this paper:}

Osman E.H., Gumaa Y.S.A., Elhag A.M.H. (2018). Land Cover/Land Use Trends along the Blue Nile River Blue Nile State - Sudan. IRA International Journal of Applied Sciences (ISSN 2455-4499), 13(1), 1-13. doi:http://dx.doi.org/10.21013/jas.v13.n1.p1

(C) Institute of Research Advances.

\section{(cc) EY-NC}

This work is licensed under a Creative Commons Attribution-Non Commercial 4.0 International License subject to a proper citation to the publication source of the work.

Disclaimer: The scholarly papers as reviewed and published by the Institute of Research Advances (IRA) are the views and opinions of their respective authors and are not the views or opinions of the IRA. The IRA disclaims of any harm or loss caused due to the published content to any party.

Institute of Research Advances is an institutional publisher member of Publishers International Linking Association Inc. (PILA-CrossRef), USA. The institute is an institutional signatory to the Budapest Open Access Initiative, Hungary advocating the open access of scientific and scholarly knowledge. The Institute is a registered content provider under Open Access Initiative Protocol for Metadata Harvesting (OAI-PMH).

The journal is indexed \& included in CAS Source Index of Chemical Abstracts Service of American Chemical Society (USA), Index Copernicus (IC Value 85.27), WorldCat Discovery Service (USA), CrossRef Metadata Search (USA), WorldCat (USA), OCLC (USA), Open J-Gate (India), EZB (Germany) Scilit (Switzerland), Airiti (China), Bielefeld Academic Search Engine (BASE) of Bielefeld University, Germany, PKP Index of Simon Fraser University, Canada. 


\begin{abstract}
The study focused on quantifying the extent and sources of the deterioration of the vegetation cover of the study area at the Sudanese Blue Nile watershed in relation to agriculture extension policy, inefficient management and Lack of governmental policy.
\end{abstract}

The Research was based on forest and vegetation inventory and soil analysis to determine the current situation using ground survey, forest inventory and remote sensing data as well as secondary information from other sources to cover historical records from 1990 to 2015.

The results showed a significant change in natural ecosystems during the study period due to the change in the land use patterns. The Closed forests, open forests, and rural settlement areas were found to decrease by $-90 \%,-43 \%$ and $-32 \%$ respectively during the period (1990-2000). This negative trend was reflected in a positive trend showed by expansion in agriculture $(+267 \%)$, horticulture $(+73 \%)$, bare land (144\%), and urban areas (12\%). During the period (2010-2015), which was the civil war period, the area of closed forests, open forests and urban areas were increased, in comparison to that of 1990-2000) by 201,10, and 247\% respectively, while that of agriculture, Rural areas, and bare lands is negative (-51, -54 and $-68 \%$ respectively).

The major factor for the change is mainly attributed to the migration of rural people towards urban areas due to civil war and economic crises. In addition, it is expected that there are other factors such as the absence of clear plans and coordination between concerned government authorities, at local and national levels, which may need further investigations and studies to clear the whole picture.

Keywords: Soil Sciences, Natural Resource, Forestry, Agriculture, Land Use

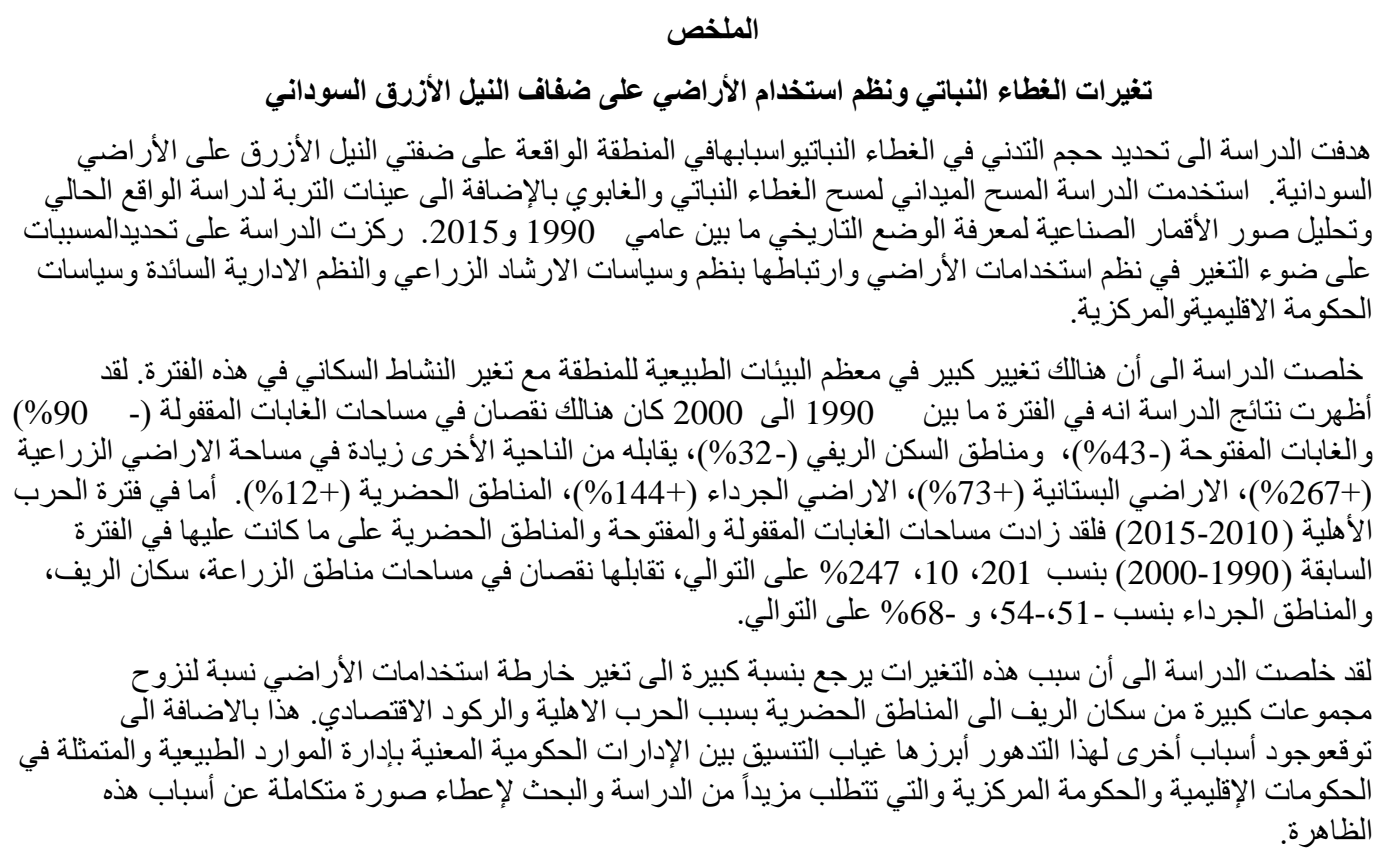

\title{
INTRODUCTION
}

Change detection, as one of the most important applications of remote sensing, determines changes both quantitatively as well as qualitatively. It rests upon the assumption that under the same atmospheric conditions and sensor characteristic the major source for difference of a pixel's brightness is a change of surface cover. There are two basic methods of change detection by mean of remote sensing, explicitly post-classification and preclassification methods (Lunetta, 1999). Land use and cover data are collected through the combination of direct observation and remote sensing, with the latter being the most widely used method (Campbell, 2007). Satellite data has been valuable in partnership with socioeconomic surveys and census data for a better understanding of land use/cover dynamics and the factors that drive them (Dale, 1997). 
Sudan is one of the largest countries in Africa with a current land area of approximately $1.882 .000 \mathrm{~km}^{2}$. The population is approximately 33.4 million $75 \%$ of whom live in rural areas. The economy depends predominantly on agriculture, which contributes to the Gross Domestic Production (GDP) by about 30\%, meanwhile, oil exports are gaining momentum. The influence of forest on the amount and timing of runoff is of great importance for planning sustainable land use in many regions around the world, not least in the Blue Nile water Catchments area (324,530 $\mathrm{km}^{2}$ ), the Blue Nile annually contribute $60 \%$ of the flow to the Nile. The annual rainfall ranges from 1200 to 1600 $\mathrm{mm} /$ year and the mean annual evapotranspiration is $1100 \mathrm{~mm} /$ year (Kim et.al. 2007).

The Blue Nile River, which originates from the steep mountains of the Ethiopian Plateau, is the major source of sediment loads in the Nile basin. Soil erosion from the upstream of the basin and the subsequent sedimentation in the downstream area is an immense problem threatening the existing and future water resources development in the Nile basin (Elhag et al, 2018). The benefits gained by the construction of micro-dams in the Upper Nile are threatened by the rapid loss of storage volume due to excessive sedimentation (El-Swaify and Hurni, 1996; Tamene et al., 2006). Moreover, the green water storage of the Ethiopian highlands, where rain-fed agriculture prevails has diminished because of topsoil loss and this has caused frequent agricultural drought (Hurni, 1993; El-Swaify and Hurni, 1996). In the downstream part of the basin, (e.g., in Sudan and Egypt) excessive sediment load led to massive operation cost of irrigation canals de-silting, and sediment dredging in front of hydropower turbines. For example, the Sinnar dam has lost $65 \%$ of its original storage after 62 years of operation (Shahin, 1993). Both the Nile Basin Initiative and the Ethiopian government are developing ambitious plans of water resources projects in the Upper Blue Nile basin, locally called the Abbay basin (BCEOM, 1999; World Bank, 2006). Thus, an insight into the soil erosion/sedimentation mechanisms and the mitigation measures play an indispensable role for the sustainable water resources development in the region.

On the other hands, humans play a major role as forces of change in the environment, inflicting environmental change at all levels ranging from the local to the global scale. The various uses of land for economic purposes have greatly transformed land cover at a global scale (Turner et al., 1994). Over the last 10,000 years, almost half of the ice-free earth surface has changed and most of the results were due to the use of land by humans (Lambinet al., 2003). The production of agricultural and forest goods specifically have caused agriculture and forestry to become the most transformative events globally; with agricultural land rivalling forest cover and occupying 35\% of the icefree land surface in 2000 (Foley et al., 2007).

In using the land to yield goods and services, humans alter ecosystems and their interactions with the atmosphere, aquatic systems, and surrounding land (Vitousek et al, 1997). Land use and cover play a key role in climate changes through the exchange of greenhouse gases, sensible heat, and local evapotranspiration. Approximately $35 \%$ of the $\mathrm{CO}_{2}$ emissions to the atmosphere were from land use (Foley et al., 2005). In addition to climate change, the growth of human population and land cover changes have two effects on the biogeochemical cycles, habitat availability, biodiversity, soil erosion, water quality, water flow, and sediment flows (Dale 1997).

The objective of the study is, therefore, was to quantify the extent and sources of the deterioration of the vegetation cover and biological diversity and their effects in the watershed of the Blue Nile River. The study is believed to be vital to mitigate the local land cover change which has a great impact on a local, regional and global scale; also the study finding will help the need of identifying the problem on similar ecosystems.

\section{Materials and Methods \\ The Study Area}

The study was carried out on a transect of $20 \mathrm{~km}$ along the Blue Nile River (10 km at each side of the river) within the Blue Nile state, that represents the direct and effective watershed area of the Blue Nile River in Sudan (Figure 1). The Blue Nile State is located at the southeastern part of Sudan in the semi-wet zone. It lies between latitudes $9.30^{\circ} \mathrm{N}$ and $12.30^{\circ} \mathrm{N}$ and longitudes $33.5^{\circ} \mathrm{E}$ and $35.3^{\circ} \mathrm{E}$, with a total area of $40000 \mathrm{~km}^{2}$ (UNEP, 2010). 


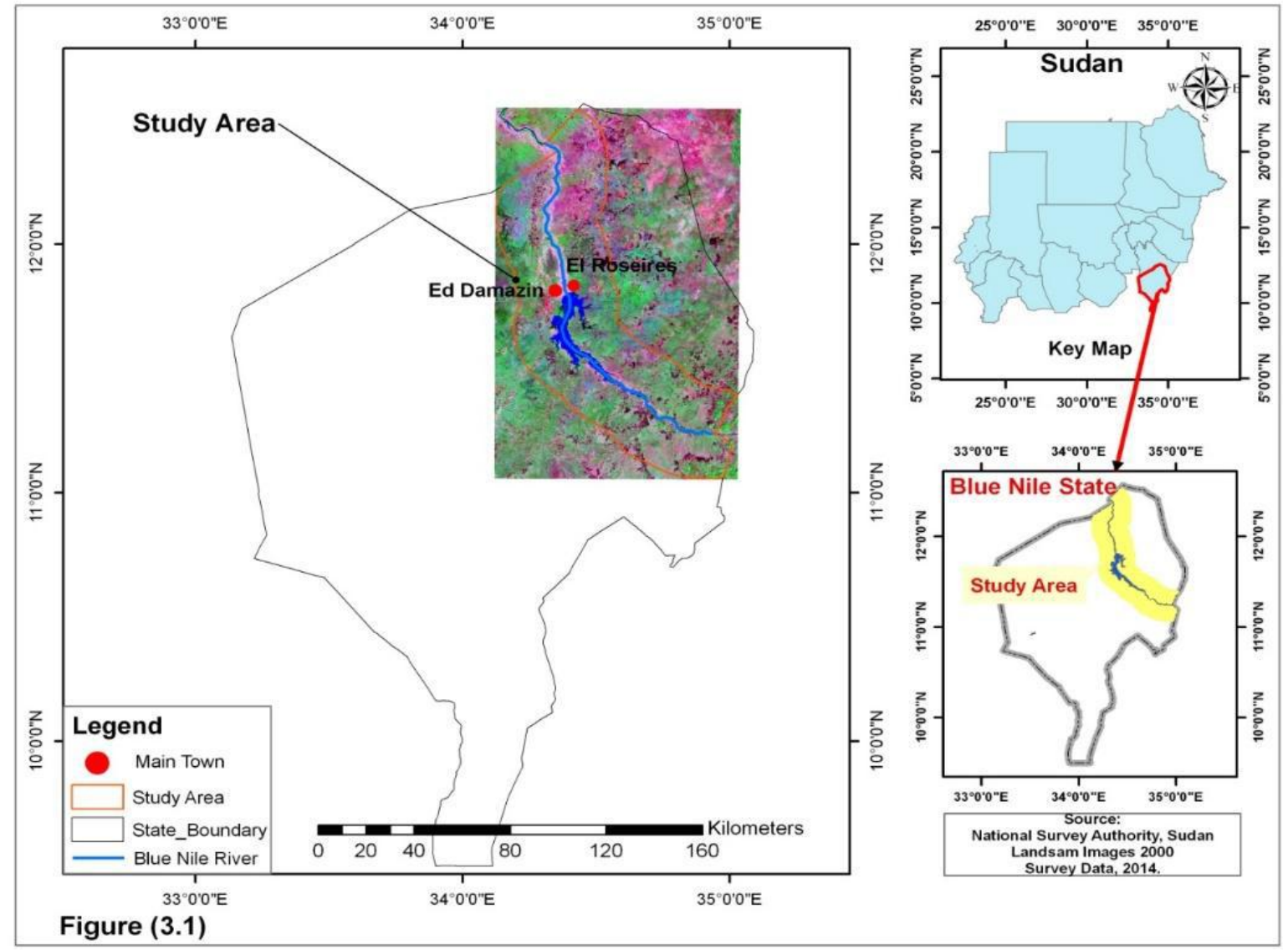

Figure 1: The Study Area

The water of the Nile and (water runways) land are the property of the government. However, surrounding land [with the exception of a limited number of flooded areas that belongs to the forest department] the majority of the lands are privately owned as a farm. The climate is typical of the high rainfall Woodland Savannah. The average annual rainfall between in the study area ranges from 750 to $1200 \mathrm{~mm}$. The relative annual humidity is between $60-$ $65 \%$ and the average annual temperature range between $35-40^{\circ} \mathrm{C}$. Tree species of the Blue Nile State have earlier been recorded Andrews, (1948); Smith,(1949); Harrison and Jackson, (1958), Gumaa, (1988). El Amin, (1990) in his study on trees and shrubs of Sudan, mentioned 106 species to occur in the Blue Nile State, belonging to 31 families including 62 genera. According to Harrison and Jackson, (1958), the species of Acacia were predominant in the drier part while the broad-leaved deciduous trees were predominant in the wetter parts.

\section{Satellite Images}

Four LANDSAT satellite images (Table 1) and Digital Elevation Models covering the study area were used. Images 2010 and 2015 were enhanced Thematic Mapper (ETM) and Landsat 8 respectively, while images 2000 and1990 were thematic mapper (TM).

DEM was used to extracts hydrological information in the study area. The characteristics of these images are shown in Table 1.

Table 1: Characteristics of imageries used in this study

\begin{tabular}{|c|c|c|c|c|c|}
\hline Image & Date & Sensor & Band & Resolution & Area $\left(\mathrm{km}^{2}\right)$ \\
\hline 1 & $15 / 11 / 1990$ & TM & $1-7$ & $30 \mathrm{M}$ & $185 \times 185$ \\
\hline 2 & $14 / 10 / 2000$ & TM & $1-7$ & $30 \mathrm{M}$ & $185 \times 185$ \\
\hline 3 & $16 / 11 / 2010$ & ETM & $1-7$ & $30 \mathrm{M}$ & $185 \times 185$ \\
\hline 4 & $10 / 11 / 2015$ & OLI/TIRS & $1-8$ & $30+15 \mathrm{M}$ & $185 X 185$ \\
\hline
\end{tabular}




\section{Path/Row for all the images: 171/52, 172/51 and 172/52}

A rectangular grid was set at the spacing of $2 \mathrm{~km}$ using fishnet techniques (scale of 1:200,000) in a north to south direction and $2 \mathrm{~km}$ in an east to west direction (Fig 2).

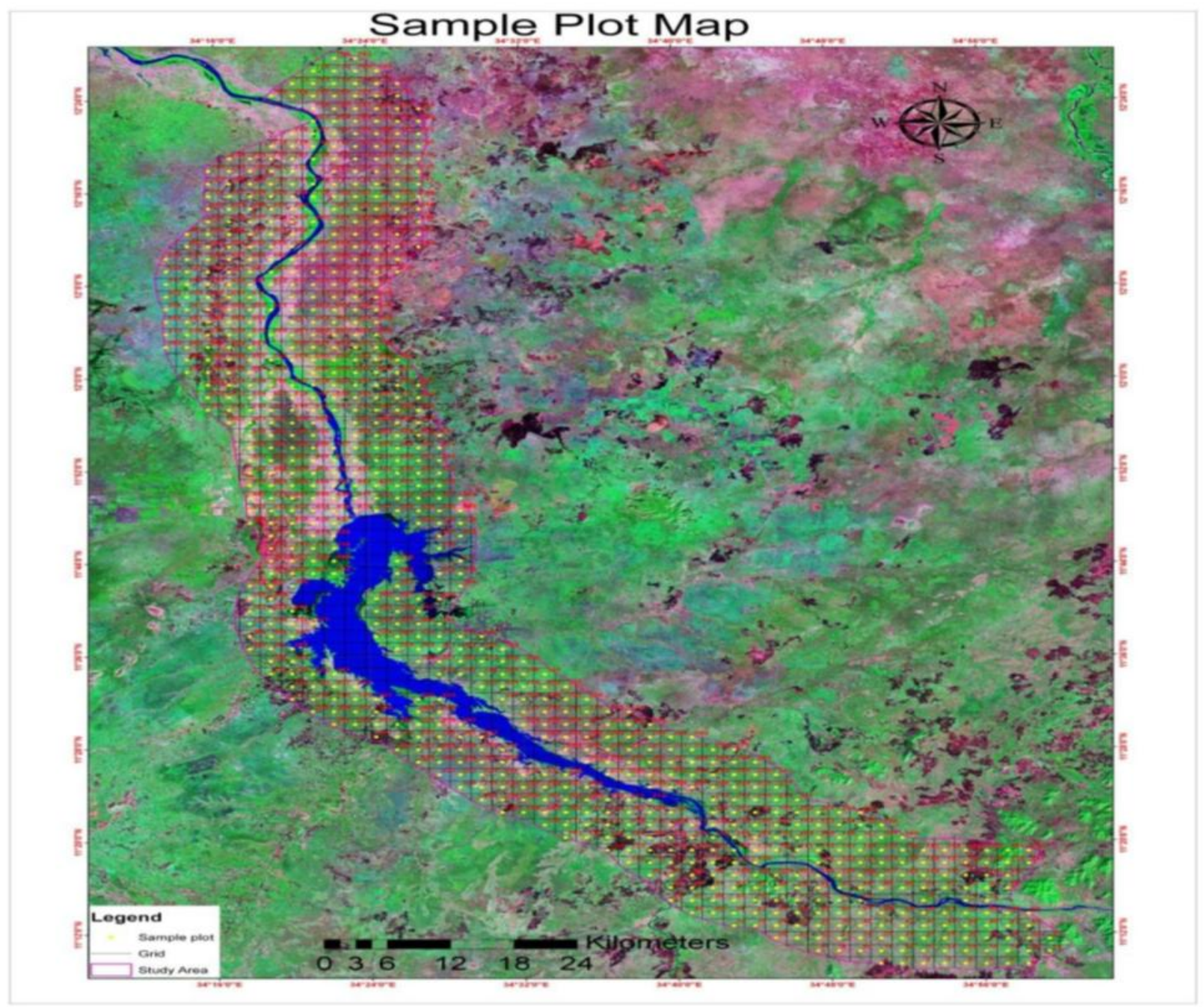

Figure 2: Field samples map (Source: This study)

\section{Forest and Vegetation Ground Survey}

A sample map was compiled using the point coordinate to select the best gridline crossing all the features. Land cover map 2010, 2012 (the Blue Nile, 2012), satellite images and a topographic sheet of the area were used to locate the area. The study area was divided into four zones: southeast of the Rosaries Dam (A), southwest of Rosaries Dam (B), northeast of Rosaries Dam (C) and northwest the Rosaries Dam (D) 783samples were taken as shown in Figure (4). Fieldwork was conducted within the period $1^{\text {st }}$ December 2015 to $5^{\text {th }}$ March, 2016 in a total area of approximately 346483.43 ha. GPS (Garmin 62C) was used to navigate among check samples and to record the coordinates ( $\mathrm{X}, \mathrm{Y}$ and $\mathrm{Z}$ values) of each check sample. The study area was a total of 783 sample plots represented by $30 \times 30 \mathrm{~m}$. In each sample plot, tree type, their number, diameter at breast height, total height, crown diameter, bole height, tree seedlings saplings, grasses, cut trees and dead trees were recorded. 


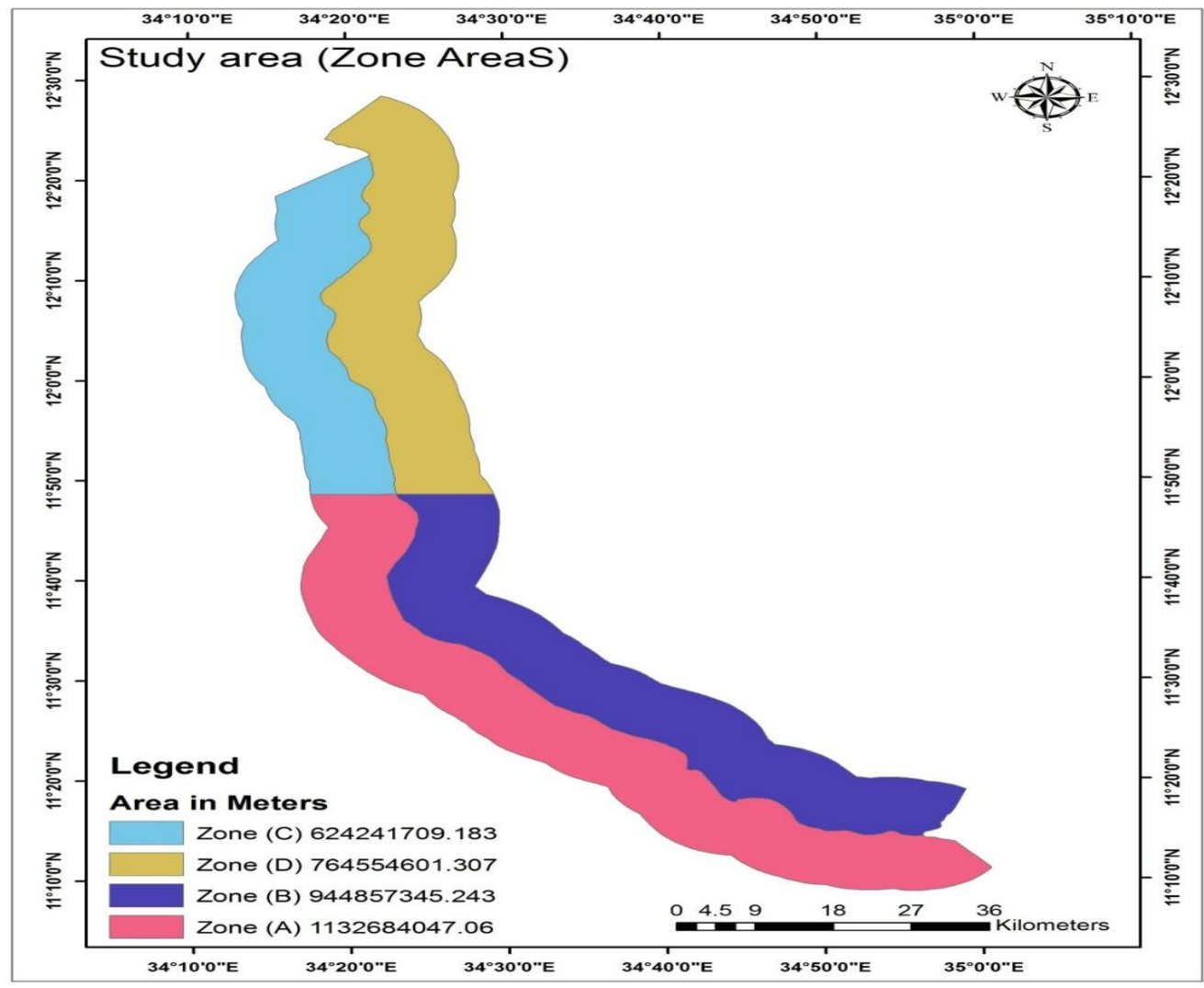

Figure 4: Field samples map

\section{Image Analyses}

Four cloud free lands at TM and ETM+ scenes covering the study area were selected for analysis. These images were acquired in seven and eight bands respectively; they covered the visible, near and middle infrared region of the electromagnetic spectrum.

Change detection was done and quantitative assessment of land degradation and land-use change was performed through map calculation option. Map calculation was also used to calculate the occurrence and extent of changes on the land surface during the period of study (1990 to 2015). Later, data extraction and segmentation were carried out for partitioning a digital image into multiple segments (sets of pixels, also known as super-pixels). Data extraction and segmentation are to simplify and/or change the representation of an image into something that is more meaningful and easier to analyze.

Soil samples $(0.5 \mathrm{~kg}$ each) were collected from the 783 sample points to cover the variability observed from satellite image analysis. Global Positioning System (GPS) was used to determine the locations of the sample points depending on satellite image interpretation and morphological and physical soil properties (colour, texture, structure...etc.). Soil samples were spread to air dry at room temperature and then grounded using wood pestles and mortars and sieved to pass $2 \mathrm{~mm}$ sieves. The samples were then kept in well-labeled plastic bags for subsequent analysis, to determine the chemical and physical properties that include: $\mathrm{pH}$ of saturated soil paste, Electrical conductivity (EC), soluble cations and anions, and Sodium Adsorption Ratio (SAR)(Klute, 1965).

\section{RESULTS AND DISCUSSION}

Tables 2 to 5 show the relative density (R.Den), Relative dominance (R.Dom) and relative frequency (R.Freq) of trees in the study area. Awide variation was found in the distribution of tree species within the four zones of the study area 
Table 2: Zone I Forest Dynamic characteristics

\begin{tabular}{|c|c|c|c|c|c|c|c|c|c|}
\hline \multirow{2}{*}{ No. } & \multirow{2}{*}{ Tree Species } & \multicolumn{4}{|c|}{ Mature Trees } & \multicolumn{2}{|c|}{ Seedlings } & \multirow{2}{*}{$\begin{array}{l}\text { Cut } \\
\text { R.Den }\end{array}$} & \multirow{2}{*}{\begin{tabular}{|c|} 
Mortality \\
R.Den \\
\end{tabular}} \\
\hline & & R.Den & R. Dom & R. Freq & IV & R.Den & R. Freq & & \\
\hline 1 & Cordia Africana & 1.76 & 2.12 & 3.34 & 7.22 & 0.00 & 0.00 & 0.00 & 0.00 \\
\hline 2 & TamarindusIndica & 0.05 & 0.06 & 0.15 & 0.26 & 0.00 & 0.00 & 0.00 & 0.00 \\
\hline 3 & TerminaliaBrownii & 0.79 & 0.72 & 1.22 & 2.72 & 0.00 & 0.00 & 0.91 & 7.69 \\
\hline 4 & HyphineThebeica & 0.05 & 0.04 & 1.52 & 1.60 & 1.50 & 2.98 & 0.00 & 1.92 \\
\hline 5 & DalbergiaMelanoxylon & 1.39 & 0.73 & 2.58 & 4.71 & 0.04 & 0.33 & 0.00 & 0.00 \\
\hline 6 & Beswelliapaprifera & 0.05 & 0.02 & 0.15 & 0.22 & 0.00 & 0.00 & 0.23 & 1.92 \\
\hline 7 & Cordiarothii & 0.09 & 0.12 & 0.15 & 0.36 & 0.00 & 0.00 & 0.00 & 0.00 \\
\hline 8 & Dacryodesedulis & 0.88 & 0.91 & 1.52 & 3.31 & 0.00 & 0.00 & 0.00 & 0.00 \\
\hline 9 & Combretumaculeatum & 23.31 & 25.10 & 17.33 & 65.74 & 4.13 & 8.94 & 16.44 & 11.54 \\
\hline 10 & Acacia senegal & 1.11 & 0.08 & 1.67 & 2.87 & 8.43 & 3.31 & 0.00 & 0.00 \\
\hline 11 & Balanitesaegyptica & 6.94 & 8.70 & 12.92 & 28.55 & 3.08 & 10.93 & 1.14 & 1.92 \\
\hline 12 & Dichrostachyuscinerea & 0.05 & 0.02 & 7.90 & 7.97 & 15.33 & 15.56 & 2.97 & 25.00 \\
\hline 13 & Acacia polyacantha & 2.68 & 1.66 & 6.99 & 11.33 & 0.06 & 0.33 & 0.00 & 0.00 \\
\hline 14 & Lanneafruticosa & 10.55 & 7.24 & 5.78 & 23.56 & 0.13 & 0.99 & 2.97 & 5.77 \\
\hline 15 & Azadirachtaindica & 0.14 & 0.28 & 0.15 & 0.57 & 0.00 & 0.00 & 0.23 & 0.00 \\
\hline 16 & Acacia seyalvar fistula & 2.27 & 1.18 & 3.80 & 7.25 & 0.19 & 0.66 & 0.00 & 0.00 \\
\hline 17 & Anogeisusleocarpus & 14.29 & 17.42 & 3.34 & 35.05 & 0.03 & 0.33 & 2.97 & 3.85 \\
\hline 18 & Ziziphusspina-christi & 2.45 & 1.74 & 6.08 & 10.27 & 32.52 & 25.83 & 0.68 & 19.23 \\
\hline 19 & Acacia nilotica & 0.23 & 0.38 & 0.30 & 0.92 & 0.00 & 0.00 & 0.00 & 0.00 \\
\hline 20 & Adansoniadigitata & 0.19 & 6.09 & 0.46 & 6.73 & 2.03 & 3.64 & 0.00 & 0.00 \\
\hline 21 & Acacia seyalvarseyal & 27.10 & 19.73 & 17.78 & 64.61 & 32.53 & 26.16 & 68.04 & 19.23 \\
\hline 22 & Pterocarpusleucinus & 1.71 & 2.28 & 2.28 & 6.27 & 0.00 & 0.00 & 0.00 & 1.92 \\
\hline 23 & Sterculiasetegira & 1.94 & 3.40 & 2.58 & 7.92 & 0.00 & 0.00 & 3.42 & 0.00 \\
\hline
\end{tabular}

More tree species are found in the southern part, south of Rosieris Dam, represented by Zone I and Zone II (Tables 2 and 3), compared to that of the northern part(north of Rosieris Dam) (Zones III and IV) as shown in Tables 4 and 5. sixteen tree species are found to exist in the south and in the north, with eleven tree species found only in the south (mostly rich savannah species) and six tree species found only in the north (mostly dry savannah and semi-desert trees). Comparing tree species south and north of the Dam, it is found that about twenty tree species are common between Zones I and II, in addition to two tree species found only in Zone I (Cordiarothii and Dichrostachyuscinerea) and four species found only in zone II (Entadaafricana, Ficussycomorus, Lanneanigritana, and Sclerocartabirrea). For the northern part of the area, fifteen tree species are common between Zones III and IV, in addition to three tree species only found in Zone III (Acacia nubica, Bauhinia rufescens and Crativaadonsonii) and four tree species found only in Zone IV (Combretumaculeatum, Ficussycomorus, Lanneafruticose and Tamarindus Indica). In terms of species densities and frequencies, the results (Tables 2 to 5) indicate that Acacia seyalvarseyal, Combretumaculeatum and Anogeisusleocarpus dominate Zone I with collective relative density of 65\%. In Zone II Combretumaculeatum, Lanneafruiticosa and Anogeisusleocarpus dominate with a collective relative frequency of $50 \%$.

Table 3: Zone II Forest Dynamic characteristics

\begin{tabular}{|c|c|c|c|c|c|c|c|c|c|}
\hline \multirow{2}{*}{ No. } & \multirow{2}{*}{ Tree Species } & \multicolumn{4}{|c|}{ Mature Trees } & \multicolumn{2}{|c|}{ Seedlings } & \multicolumn{2}{|c|}{ Cut Mortality } \\
\hline & & R.Den & R. & R. Freq & IV & R.Den & R. Freq & R.Den & R.Den \\
\hline 1 & Cordia Africana & 0.06 & 0.03 & 0.23 & 0.32 & 0.00 & 0.00 & 0.00 & 0.00 \\
\hline 2 & TamarindusIndica & 0.06 & 0.04 & 0.23 & 0.33 & 0.00 & 0.00 & 0.00 & 0.00 \\
\hline 3 & TerminaliaBrownii & 0.43 & 0.36 & 0.69 & 1.47 & 0.16 & 0.29 & 0.00 & 0.00 \\
\hline 4 & HyphineThebeica & 0.12 & 0.06 & 0.46 & 0.64 & 3.31 & 3.24 & 0.41 & 0.00 \\
\hline 5 & DalbergiaMelanoxylon & 1.28 & 0.32 & 2.97 & 4.57 & 0.63 & 1.18 & 1.64 & 0.00 \\
\hline 6 & Beswelliapaprifera & 9.65 & 5.74 & 3.20 & 18.60 & 0.00 & 0.00 & 0.62 & 0.00 \\
\hline 7 & Dacryodesedulis & 0.24 & 0.23 & 0.23 & 0.71 & 0.00 & 0.00 & 0.00 & 0.00 \\
\hline 8 & Ficussy & 0.49 & 2.42 & 0.69 & 3.59 & 0.00 & 0.00 & 0.00 & 0.00 \\
\hline 9 & Combretumaculeatum & 21.01 & 16.27 & 15.33 & 52.61 & 4.98 & 8.82 & 35.52 & 29.63 \\
\hline 10 & Acacia senegal & 1.76 & 0.72 & 2.97 & 5.45 & 6.49 & 8.53 & 4.52 & 0.00 \\
\hline 11 & Balanitesaegyptica & 8.93 & 14.23 & 16.02 & 39.17 & 3.17 & 8.24 & 4.31 & 22.22 \\
\hline 12 & Sclerocartabirrea & 0.67 & 0.54 & 1.83 & 3.03 & 0.06 & 0.59 & 0.00 & 0.00 \\
\hline
\end{tabular}


IRA-International Joumal of Applied Sciences

\begin{tabular}{|c|l|c|c|c|c|c|c|c|c|}
13 & Acacia polyacantha & 5.04 & 1.97 & 1.60 & 8.61 & 0.28 & 0.59 & 6.57 & 0.00 \\
\hline 14 & Lonchocarpuslaxiflorus & 0.18 & 0.15 & 0.69 & 1.02 & 0.00 & 0.00 & 0.62 & 3.70 \\
\hline 15 & Lanneanigritana & 0.18 & 0.13 & 0.46 & 0.77 & 0.00 & 0.00 & 0.00 & 0.00 \\
\hline 16 & Lanneafruticosa & 13.66 & 6.42 & 10.98 & 31.06 & 2.25 & 3.24 & 10.88 & 7.41 \\
\hline 17 & Azadirachtaindica & 0.30 & 1.03 & 0.69 & 2.02 & 0.09 & 0.59 & 0.00 & 0.00 \\
\hline 18 & Acacia seyalvar fistula & 0.85 & 0.45 & 1.60 & 2.90 & 0.71 & 7.06 & 0.00 & 0.00 \\
\hline 19 & Anogeisusleocarpus & 8.93 & 13.84 & 5.95 & 28.72 & 3.09 & 2.06 & 1.03 & 3.70 \\
\hline 20 & Entadaafricana & 2.06 & 0.46 & 1.60 & 4.13 & 0.00 & 0.00 & 0.00 & 0.00 \\
\hline 21 & Ziziphusspina-christi & 2.73 & 0.85 & 5.72 & 9.30 & 36.12 & 27.35 & 1.03 & 0.00 \\
\hline 22 & Acacia nilotica & 0.30 & 1.08 & 0.69 & 2.07 & 0.44 & 1.47 & 0.00 & 0.00 \\
\hline 23 & Adansoniadigitata & 0.12 & 1.92 & 0.46 & 2.50 & 0.00 & 0.00 & 0.00 & 0.00 \\
\hline 24 & Acacia seyalvarseyal & 15.12 & 9.01 & 13.73 & 37.86 & 38.20 & 26.76 & 32.85 & 27.78 \\
\hline 25 & Pterocarpusleucinus & 3.28 & 4.91 & 5.26 & 13.45 & 0.00 & 0.00 & 0.00 & 5.56 \\
\hline 26 & Sterculiasetegira & 2.55 & 16.88 & 5.72 & 25.15 & 0.00 & 0.00 & 0.00 & 0.00 \\
\hline
\end{tabular}

In Zone III and IV Balanitesaegyptica, Acacia nilotica and Acacia seyalvarseyal were the dominate species in these two zones with the total relative frequency of $78 \%$, and $80 \%$ respectively. However, for all the four zones, Balanitesaegypticanilotica and Acacia seyalvarseyal are found to be the most frequent species partly due to their resistance to the environmental conditions and partly due to their palatability to grazing animals particularly goat that contribute positively to their distribution in wide areas.

Table 4: Zone III Forest Dynamic characteristics

\begin{tabular}{|c|c|c|c|c|c|c|c|c|c|}
\hline \multirow{2}{*}{ No. } & \multirow{2}{*}{ Tree Species } & \multicolumn{4}{|c|}{\begin{tabular}{|l|} 
Mature Trees \\
\end{tabular}} & \multicolumn{2}{|c|}{ Seedlings } & \multicolumn{2}{|c|}{\begin{tabular}{l|l} 
Cut & Mortality \\
\end{tabular}} \\
\hline & & R.Den & R. Dom & R. Freq & IV & R.Den & R. Freq & R.Den & R.Den \\
\hline 1 & Crativaadonsonii & 0.92 & 5.19 & 1.49 & 7.61 & 0.00 & 0.00 & 0.00 & 0.00 \\
\hline 2 & HyphineThebeica & 0.00 & 0.00 & 0.00 & 0.00 & 2.70 & 4.39 & 0.00 & 0.00 \\
\hline 3 & Acacia senegal & 12.92 & 1.36 & 4.48 & 18.76 & 1.35 & 15.40 & 7.41 & 0.00 \\
\hline 4 & Balanitesaegyptica & 19.69 & 29.79 & 38.81 & 88.29 & 18.92 & 8.25 & 6.02 & 0.00 \\
\hline 5 & Acacia polyacantha & 0.00 & 0.00 & 0.00 & 0.00 & 1.01 & 0.71 & 0.00 & 0.00 \\
\hline 6 & Lonchocarpuslaxiflorus & 0.62 & 0.52 & 1.49 & 2.63 & 0.00 & 0.00 & 0.00 & 0.00 \\
\hline 7 & Acacia milifra & 0.00 & 0.00 & 0.00 & 0.00 & 0.34 & 0.02 & 0.00 & 0.00 \\
\hline 8 & Bauhil & 0.00 & 0.00 & 0.00 & 0.00 & 1.01 & 0.10 & 0.00 & 0.00 \\
\hline 9 & Acacia nubica & 0.00 & 0.00 & 0.00 & 0.00 & 12.16 & 14.51 & 0.00 & 0.00 \\
\hline 10 & Khayasenegalensis & 0.00 & 0.00 & 0.00 & 0.00 & 0.34 & 0.02 & 0.00 & 0.00 \\
\hline 11 & Azadirachtaindica & 1.23 & 1.45 & 2.99 & 5.66 & 0.68 & 0.25 & 0.00 & 0.00 \\
\hline 12 & Acacia seyalvar fistula & 0.00 & 0.00 & 0.00 & 0.00 & 0.34 & 0.20 & 0.00 & 0.00 \\
\hline 13 & Anogeisusleocarpus & 1.85 & 5.92 & 2.99 & 10.75 & 0.34 & 0.05 & 0.00 & 0.00 \\
\hline 14 & Ziziphusspina-christi & 2.77 & 2.66 & 5.97 & 11.40 & 28.04 & 20.05 & 0.00 & 0.00 \\
\hline 15 & Acacia nilotica & 25.54 & 49.01 & 8.96 & 83.51 & 6.42 & 2.21 & 13.89 & 0.00 \\
\hline 16 & Adansoniadigitata & 0.00 & 0.00 & 0.00 & 0.00 & 0.34 & 0.13 & 0.00 & 0.00 \\
\hline 17 & Acacia seyalvarseyal & 34.46 & 4.09 & 32.84 & 71.38 & 25.68 & 33.67 & 71.30 & 0.00 \\
\hline 18 & Sterculiasetegira & 0.00 & 0.00 & 0.00 & 0.00 & 0.34 & 0.0495 & 1.39 & 0.00 \\
\hline
\end{tabular}

Table 5: Zone IV Forest Dynamic characteristics

\begin{tabular}{|c|c|c|c|c|c|c|c|c|c|}
\hline \multirow{2}{*}{ No. } & \multirow{2}{*}{ Tree Species } & \multicolumn{4}{|c|}{ Mature Trees } & \multicolumn{2}{|c|}{ Seedlings } & \multicolumn{2}{|c|}{ Cut Mortality } \\
\hline & & R.Den & R. Dom & $\mathbf{R}$. & IV & R.Den & R. Freq & R.Den & R.Den \\
\hline 1 & TamarindusIndica & 0.28 & 0.08 & 0.56 & 0.91 & 0.00 & 0.00 & 0.00 & 0.00 \\
\hline & HyphineThebeica & 0.00 & 0.00 & 0.00 & 0.00 & 0.00 & 0.00 & 5.76 & 0.00 \\
\hline 2 & Ficussycomorus & 0.28 & 0.68 & 0.56 & 1.51 & 0.00 & 0.00 & 0.00 & 0.00 \\
\hline 3 & Combretumaculeatum & 0.28 & 0.17 & 0.56 & 1.00 & 0.00 & 0.00 & 0.00 & 0.00 \\
\hline 4 & Acacia senegal & 1.38 & 0.39 & 1.68 & 3.45 & 0.54 & 0.72 & 0.00 & 0.00 \\
\hline 5 & Balanitesaegyptica & 32.23 & 29.72 & 53.07 & 115.02 & 9.30 & 12.53 & 32.98 & 0.00 \\
\hline 6 & Acacia polyacantha & 0.83 & 0.34 & 1.12 & 2.29 & 4.44 & 5.78 & 1.05 & 68.75 \\
\hline 7 & Lonchocarpuslaxiflorus & 0.55 & 1.29 & 1.12 & 2.96 & 0.00 & 0.00 & 0.00 & 0.00 \\
\hline 8 & Acacia nubica & 0.28 & 0.01 & 0.56 & 0.84 & 22.40 & 17.83 & 0.00 & 9.37 \\
\hline 9 & Lanneafruticosa & 1.93 & 0.11 & 0.56 & 2.59 & 0.01 & 0.24 & 0.00 & 0.00 \\
\hline 10 & & 3.58 & 1.42 & 0.56 & 5.56 & 0.00 & 0.00 & 0.00 & 0.00 \\
\hline
\end{tabular}




\begin{tabular}{|c|l|c|c|c|c|c|c|c|c|}
11 & Azadirachtaindica & 7.44 & 13.46 & 6.15 & 27.04 & 0.55 & 0.24 & 0.52 & 0.00 \\
\hline 12 & Acacia seyalvar fistula & 6.34 & 2.71 & 8.94 & 17.99 & 8.66 & 9.88 & 1.57 & 0.00 \\
\hline 13 & Anogeisusleocarpus & 0.28 & 0.13 & 0.56 & 0.96 & 0.01 & 0.24 & 0.00 & 0.00 \\
\hline 14 & Ziziphusspina-christi & 3.31 & 1.87 & 2.79 & 7.97 & 25.58 & 24.34 & 4.71 & 0.00 \\
\hline 15 & Acacia nilotica & 23.97 & 31.05 & 3.35 & 58.37 & 3.42 & 5.54 & 5.24 & 0.00 \\
\hline 16 & Adansoniadigitata & 2.20 & 12.58 & 1.68 & 16.46 & 0.00 & 0.00 & 0.00 & 0.00 \\
\hline 17 & Acacia seyalvarseyal & 13.77 & 3.29 & 13.97 & 31.03 & 24.47 & 22.41 & 47.12 & 21.87 \\
\hline 18 & Sterculiasetegira & 1.10 & 0.73 & 2.23 & 4.07 & 0.61 & 0.241 & 1.05 & 0.00 \\
\hline
\end{tabular}

The variation of tree species distribution is considered to be normal if soil types are taken into consideration (Table 6). It is clear that the southern part of the study area is characterized mainly by clay soil (more than $55 \%$ of the total area), while that of the northern part is mainly loamy soil (more than 55\% of the total area). Taking also in to consideration the variation in the annual amount of rainfall varies between the southern and northern parts with the range of 450-700 mm (Blue Nile investment Map, 2004).

Table 6: Types of Soil texture in the study area (\% of zone area)

\begin{tabular}{|c|c|c|c|c|}
\hline \multirow{2}{*}{ Texture } & \multicolumn{4}{|c|}{ Zone } \\
\cline { 2 - 5 } Clay & I & II & III & IV \\
\hline Clay loam & 61 & 56 & 6 & 8 \\
\hline Loam & 2 & 2 & 16 & 10 \\
\hline Rock & 14 & 11 & 56 & 58 \\
\hline Sand & 1 & 0 & 0 & 0 \\
\hline Sandy clay & 0 & 0 & 2 & 2 \\
\hline Sandy clay loam & 10 & 9 & 13 & 10 \\
\hline Sandy loam & 6 & 16 & 0 & 4 \\
\hline Silty clay loam & 1 & 7 & 6 & 8 \\
\hline
\end{tabular}

As far as the tree and vegetation dynamics are concerned, human factors are believed to be of major concern compared to the environmental factors such as micro and macroclimatic factors, as the rate of change is rapid and sometimes abrupt in case of human factors. Results shown in Table 7 present a case where only mature trees are found in the area with no seedlings even though there was no sign of past cuttings or dead trees. Such a case is characteristic of either heavy grazing, surface fires, drought or combination of them.

Table 7: Tree dynamics Category A

\begin{tabular}{|l|l|l|l|}
\hline \multicolumn{1}{|c|}{ Mature trees only- no seedlings-no cuttings or mortality } \\
\hline ZONE I & \multicolumn{2}{|c|}{ ZONE II } & \multicolumn{2}{c|}{ ZONE III } & \multicolumn{1}{c|}{ ZONE IV } \\
\hline Cordiaafricana & Cordiaafricana & Crativaadansonii & Tamarindusindica \\
\hline Tamarindusindica & Tamarindusindica & Loncocarpuslaxiflorus & Combretumglutinosum \\
\hline Cordiarothii & Dacryodesedulis & & Loncocarpuslaxiflorus \\
\hline Dacryodesedulis & Ficussycomurs & & Khayaseneglansis \\
\hline Acacia nilotica & Entadaafricana & & Adansoniadigitata \\
\hline & Adansoniadigitata & & \\
\hline & Sterculiasetigera & & \\
\hline
\end{tabular}

The tree species are shown in Table 7 represent collective frequencies of about $2 \%, 6 \%, 2 \%$ and $7 \%$ in Zones I, II, III, and IV respectively (Tables 2 to 5). All these species characterized by their broad leaves, palatability to grazing animals, low seedling resistance to drought and ground fires, and little use to the local community in terms of woody material. As such, trees of this category are left to their biological rotation with no natural replacement. Accordingly, the future of these species in the indicated zones is unpredictable unless some measures are taken, the least of which should be put in the list of endangered tree species. Results are shown in Table 8 present a case where only mature trees are found in the area with no seedlings but signs of past cuttings or dead trees are recorded. Such case is only found in Zone I and II but not in III and IV. Category B species is considered to have the same characteristics as those of category A but in addition, species of this category are subjected to illicit cutting and natural mortality. As such, they are expected to disappear earlier than tree species belong to category A, which necessitate double attention and more care. 
Table 8: Tree dynamics Category B

\begin{tabular}{|c|c|c|c|}
\hline \multicolumn{4}{|c|}{ Mature trees with no seedlings- cuttings and mortality } \\
\hline ZONE I & ZONE II & ZONE III & ZONE IV \\
\hline Terminaliabrownii & Beswelliapaprifera & & \\
\hline Beswelliapaprifera & Loncocarpuslaxiflorus & NIL & NIL \\
\hline Azadirchtaindica & Sterculiasetigera & & \\
\hline Petrocarpusleucinus & & & \\
\hline Sterculiasetigera & & & \\
\hline
\end{tabular}

Tree species of category C (Table 9) and D characterized by the presence of both mature trees and seedlings with the difference that no or little cuttings and mortality are recorded in the first one.

Table 9: Tree dynamics Category $\mathrm{C}$

\begin{tabular}{|l|l|l|l|}
\hline \multicolumn{4}{|c|}{ Mature trees with seedlings -no cuttings or mortality } \\
\hline \multicolumn{1}{|c|}{ ZONE I } & \multicolumn{1}{c|}{ ZONE II } & ZONE III & ZONE IV \\
\hline Delbergiamelanoxylon & Terminaliabrownii & Azadirchtaindica & Acacia senegal \\
\hline Acacia senegal & Sclerocaryabirrea & Anogeissusleocarpus & Lanneafruticosa \\
\hline Acacia polyacantha & Azadirchtaindica & Ziziphusspina-christi & \\
\hline Acacia seyal-varfestiula & Acacia seyal-varfestiula & & \\
\hline Adansoniadigitata & Acacia nilotica & & \\
\hline
\end{tabular}

These two categories are considered more stable and need relatively less care due to positive natural regeneration. It is very clear from Table 10 that category $\mathrm{D}$ species are mostly Acacias or thorny trees that are adapted to harsh environmental conditions, and at the same time they characterized by high palatability to grazing animals that help in their distribution an wide areas.

Table10: Tree dynamics Category D

\begin{tabular}{|l|l|l|l|}
\hline \multicolumn{4}{|c|}{ Mature trees with seedlings-plus cuttings and mortality } \\
\hline \multicolumn{1}{|c|}{ ZONE I } & \multicolumn{1}{|c|}{ ZONE II } & \multicolumn{1}{c|}{ ZONE III } & ZONE IV \\
\hline Hyphinetheibaca & Hyphinetheibaca & Acacia senegal & Balanitesaegyptica \\
\hline Combretumaculeatum & Delbergiamelanoxylon & Balanitesaegyptica & Acacia polyacantha \\
\hline Balanitesaegyptica & Combretumaculeatum & Acacia nilotica & Acacia nubica \\
\hline Dichrostachyuscinerea & Acacia senegal & Acacia seyal-varseyal & Azadirchtaindica \\
\hline Lanneafruticosa & Balanitesaegyptica & & Acacia seyal- \\
\hline Anogeissusleocarpus & Acacia polyacantha & & Ziziphusspina-christi \\
\hline Ziziphusspina-christi & Lanneabarteri & & Acacia nilotica \\
\hline Acacia seyal-varseyal & Anogeissusleocarpus & & Acacia seyal-varseyal \\
\hline & Ziziphusspina-christi & & Sterculiasetigera \\
\hline & Acacia seyal-varseyal & & - \\
\hline
\end{tabular}

Tree species in category E (Table 11), which are found only in Zone III, represent the group that disappeared or about to disappear from the species map of the indicated Zone. The present status of this category is a typical future status of tree species at category A and B if no immediate measures are taken. The main causes of such condition may be due to either over exploitation by both local community and their animals, unsuitable environmental conditions (out of their home range), changing growth factors, or combination of them.

Table 11: Tree dynamics Category $E$

\begin{tabular}{|c|c|c|c|}
\hline \multicolumn{4}{|c|}{ No mature trees or seedlings-only died or cut trees } \\
\hline ZONE & ZONE II & ZONE III & ZONE IV \\
\hline \multirow{9}{*}{ NIL } & \multirow{9}{*}{ NIL } & Hyphinetheibaca & \multirow{9}{*}{ NIL } \\
\hline & & Acacia polyacantha & \\
\hline & & Acacia mellifera & \\
\hline & & Bauhinia rufescens & \\
\hline & & Acacia nubica & \\
\hline & & Khayasenegalensis & \\
\hline & & Acacia seyal-varfestiula & \\
\hline & & Adansoniadigitata & \\
\hline & & Acacia seyal-varseyal & \\
\hline
\end{tabular}


Table 12 shows the trend in the land cover and land use system in the study area in the past 15 years in the period between 1990 and 2015. This period witnessed great variations in the environmental conditions mainly the amount of rainfall and temperature, and in the population size and distribution due to civil war and drought. The period 1990 - 2000 represents the pre-war, while $2000-2010$ is the conflict period, and $2011-2015$ was relatively stable period.

Table 12: Land cover/Land use trends

\begin{tabular}{|l|c|c|c|c|}
\hline \multirow{2}{*}{ Land use/Land cover } & Area in 1990 & \multicolumn{3}{|c|}{ Percentage Change (\%) } \\
\cline { 4 - 6 } & $(\mathbf{h a})$ & $\mathbf{2 0 0 0}$ & $\mathbf{2 0 1 0}$ & $\mathbf{2 0 1 5}$ \\
\hline Closed Forest & 85768.02 & -90 & -93 & -80 \\
\cline { 1 - 3 } Open Forest & 128161.5 & -43 & -62 & -58 \\
\hline Agriculture & 45341.55 & +267 & +286 & -141 \\
\hline Horticulture & 9784.85 & +73 & +124 & +94 \\
\hline Bare land & 2967.87 & +144 & +243 & +10 \\
\hline Urban & 6042.47 & +12 & +76 & +509 \\
\hline Rural & 14679.81 & -32 & +11 & -49 \\
\hline
\end{tabular}

Results of supervised classification of the area

The period 1990-2000 showed negative trends in the total area covered by closed and opened forests and positive trends for those of agriculture, horticulture, Urban, rural and bare land. Expansion in areas covered by agriculture, horticulture and bare lands $(+132259.2 \mathrm{ha})$ is found to be almost equivalent to areas lost by closed and open forest ($132488 \mathrm{ha}$ ). This reflects the current behaviour where licenses to farmers are granted (after paying fees) for new farms (without consulting forest authorities). Most of these farmers do not actually cultivate the land but run after the revenue gained from firewood/charcoal obtained from cleaning forest trees from the land (after paying fees to forest authorities). In the absence of clear marks of responsibilities and effective coordination between the concerned government authorities, this practice is still going on and expected to continue for a long time since both agriculture and forest authorities are more concern about license fees. Thus the result of this study clearly documents the fact that the current trend in the expansion of mechanized agriculture (real or fake) will lead to the decrease of forested area and to an increase of the bare land area.

On the other hand, the increase of the bare land area during this period could also be attributed to the expansion of urban areas at the expense of forested area due to the migration of the displaced rural people as the result of tribal conflicts, civil war, or drought. The displaced rural people usually settle in the vicinity of towns and start trading in forest products mainly firewood and charcoal. This practice leads to complete destruction of natural forest in the area as is the case of Elnour natural forest reserve, which was converted from closed multi-species forest to small islands of degraded and bare lands. The same practice is also going on around Elgarri natural forest reserve to the east of Elnour forest that host a huge camp of displaced rural people. However, the migration from rural people towards urban areas is a give-and-take phenomenon whereby forests are found to flourish in the hot war area and disappear around urban areas. Table 12 also shows an opposite trend for the period 2010-2015 compared to that of 1990-2000, where areas of closed and opened forests increased and those of agriculture, horticulture, and bare land decreased. Connecting this to the large increase of urban areas (+509\%) and a decrease of the rural areas (-49\%) for the period 2010-2015. This trend reflects typical civil war characteristics where people rush towards safe areas (urban) leaving behind forests and their homelands (rural) and agricultural lands untouched.

In general, it is clear that forest and vegetation dynamics in the study area are more influenced by human factors rather than environmental factors, especially during the civil war period. The existence of only mature trees of some species without natural seedlings is expected to be the effect of animal grazing and ground fire. Such phenomenon is found around large villages, which normally own significant herds of goats. On the other hands, the presence of some tree species with their seedlings in the presence of both illicit cutting and/or natural mortality may be due to species adaptability to local conditions, resistance to ground fires and mostly not in the menu of the local uses. Most of the tree species that belong to this later category are Acacias and some thorny tree species. Although the development trends of the land cover/land use categories are opposite to each other before and after the civil war period, still the total area under forest cover in year 2015 is far beyond that of the base year (1990) where the closed and open forests represent only $20 \%$ and $42 \%$ of 1990 areas respectively. 


\section{CONCLUSION}

The results obtained from the analysis of field data showed that there are differences in the land use/ land cover and soil properties within and between the study zones, and this change had a negative impact on vegetation cover. The observed forest degradation was mainly due to negative human activities such as illicit tree cutting, overgrazing and forest fires.

There are different signs of forest degradation in the study area as Judged by a change in patterns of land use and land cover types, this change indicated a decrease of broadleaf species, which replaced by Acacia species, towards the south of the study area. Forest cover across the four zones varied according to variation in land use types and site characteristics. Special consideration in any planned intervention for revalidation is required in terms of species frequency, abundance and domain.

\section{RECOMMENDATIONS.}

The study suggested some recommendations that are expected to contribute to the design of appropriate and ideal land use systems rehabilitation of the forest cover with the objective of reducing deforestation of the study area.

Rapid changes in land cover and land use with negative human impact activities such as urbanization and conversion of land from use to another should be addressed through taking serious measures, which may include:

1. Periodical assessment and monitoring of natural resources using remote sensing methods.

2. Increase the awareness of the local community to the importance of species diversity and the adoption of agroforestry systems, as well as the continuation of the afforestation and reforestation programs.

3. Coordination between different government authorities related to agriculture, natural resources and environmental issues to avoid mismanagement.

\section{References}

[1]. Andrews, F.W. (1948). Vegetation of the Sudan. In: Agriculture in the Sudan (ed. J.D. Tothil), Oxford University Press.

[2]. BCEOM (1999). Abay River Basin integrated development master plan, Phase 2, main report-Vol. 1, Ministry of water resources, Addis Ababa., Agriculture, 1-2.

[3]. Blue Nile Investment Map, (2012). Blue Nile Working plan, Blue Nile State

[4]. Campbell, J. L. (2007) 'Why Would Corporations Behave in Socially Responsible Ways? Institutional Theory of Corporate Social Responsibility', Academy of Management Review, 32, 946-967.

[5]. Klute, A., 1965, Laboratory Measurement. Methods of Soil Analyses (ed. C.A. Black). Madison

[6]. Dale, V. H. (1997). The relationship between land-use change and climate change. Ecological Applications 7:753-769.

[7]. El Amin, H. M. (1990). Trees \& Shrubs of the Sudan. Ithaca Press, Exeter. Economic Policies for Sustainable Resource Development: Models Applied to the Sudan". Ph.D. thesis, Erasmus University Rotterdam.).

[8]. El-Swaify, S. and Hurni, H. (1996). Trans boundary Effects of Soil Erosion and Conservation in the Nile Basin. Land Husbandry, 1, 7-210.

[9]. Foley, J. A., De Fries, R., Asner, G. P., Barford, C., Bonan, G., S. R. Carpenter, S. R., (2005). Global Consequences of Land Use," Science, Vol. 309, No. 5734, pp. 570-574.

[10]. Foley J. A., Asner, G. P., Costa, M. H., Coe, M. T., De Fries, R., Gibbs, H. K., Howard, E. A., Olson, S., Patz, J., Ramankutty, N., Snyder, P. (2007). Amazonia revealed: forest degradation and loss of ecosystem goods and services in the Amazon basin. Front Ecol. Environ 5:25-32.

[11]. Gumaa. A. G. N. (1988). The Flora of Ingessana Hills with special Reference to Khors, S. E. Sudan (Unpublished) Ph.D. Thesis.University of Khartoum.

[12]. Harrison, M. N. and Jackson, J. K. (1958). Ecological vegetation classification of cover of Sudan. Forest Bulletin No.2 (New Series), Forests Department, Khartoum Sudan.

[13]. Elhag A.M.H., Gumaa Y.S.A., Osman E.H. (2018). Monitoring, Predicting and Quantifying Soil Alkalinity, Sodicity and Salinity in Blue Nile State, Sudan, Using Soil Techniques, Remote Sensing and GIS Analysis; Case Study: Blue Nile River. IRA International Journal of Applied Sciences (ISSN 2455-4499), 11(3), 37-45. doi: http://dx.doi.org/10.21013/jas.v11.n3.p2

[14]. Hurni, H., (1993). Land degradation, famines and resource scenarios in Ethiopia. pp. 27-62. In: Pimentel, D. (Ed.). World Soil Erosion and Conservation. Cambridge.

[15]. Lambin, E. F., Geist, H. J., Lepers, E., (2003). Dynamics of land-use and land-cover change in tropical regions. Annual Review of Ecology Evolution and Systematics28, 205-241.

[16]. Lunetta, R.S. (1999). Application, Project, and Analytical Approach. In: Remote Sensing change Detection Environmental Monitoring Methods and Applications. R.S. Lunetta and C.D. Elvidge (eds) Taylor \& Francis Ltd., London. 
[17]. Kim, Y. S., Morgan, M. J., Choki, S., and Liu, Z. G. (2007). Mol. Cell 26, 675-687.

[18]. Meteorology Office-Damazin, (2017). Blue Nile State. Metrological Office Report, October 2017.

[19]. Shahin, M. M. A. (1993). An overview of reservoir sedimentation in some African River basins. Sediment Problems: Strategies for Monitoring, Prediction and Control (Proceedings of the Yokohama Symposium, July 1993). LAHS Publ. no. $217,1993$.

[20]. Smith, J., (1949). Distribution of tree species in the Sudan in relation to rainfall and soil texture. Bulletin No. 4. Sudan Ministry of Agriculture, Khartoum.

[21]. Tamene, L., Park, S. J., Dikau R., P. and Vlek, L. G. (2006). Analysis of factors determining sediment yield variability in the highlands of northern Ethiopia. Gemprphology 76: 76-91.

[22]. Turner, I. M., Tan, H. T. W., Wee, Y. C., Ali I. ,Chew, P. T. and Corlett, R. T. (1994). A study of plant species extinction in Singapore: lessons for the conservation of tropical biodiversity. Conservation Biology, 8, 705-712.

[23]. UNEP, United Nations Environment Program (2010). Report of the third adhoc intergovernmental and multistakeholder meeting on an intergovernmental science-policy platform on biodiversity and ecosystem services. UNEP/IPBES/3/3. (2010).

[24]. Vitousek P. M., Mooney, H. A., Lubchenco, J. and Melillo, J. M. (1997). Human domination of Earth's ecosystems. Science 277:494-499.

[25]. World Bank, (2006). Interim Country Assistance Strategy, May 2006, Washington D.C.: The World Bank. 